\section{Comparison of the vasodilator effects of thiopentone and pentobarbitone}

Tsutomu Yakushiji MD, Kumi Nakamura MD, Yoshio Hatano MD, * Kenjiro Mori MD FCAnaesth
The aim of this study was to elucidate the vasodilator mechanisms of barbiturates. In helical strips of dog mesenteric artery, the effects of pretreatment with thiopentone and pentobarbitone on the contractions induced by $\mathrm{KCl}\left(2.0 \times 10^{-2} \mathrm{M}\right)$ and norepinephrine $\left(10^{-5} \mathrm{M}\right)$ in normal bathing fluid, and those induced by norepinephrine and caffeine $\left(2.5 \times 10^{-2} \mathrm{M}\right)$ in $\mathrm{Ca}^{++}$. free fluid were tested, and their effects on caffeine-induced contractions in skinned strips were also examined. Thiopentone, at concentrations over $10^{-4} \mathrm{M}$, inhibited the $\mathrm{KCl}$-induced contractions in normal bathing fluid and those induced by caffeine in $\mathrm{Ca}^{++}$-free fluid and, at concentrations over $3 \times 10^{-4}$ $M$, inhibited norepinephrine-induced contractions in normal and $\mathrm{Ca}^{++}$-free bathing fluids significantly. Pentobarbitone, at concentrations over $3 \times 10^{-4} \mathrm{M}$, inhibited $\mathrm{KCl}$ - and norepinephrine-induced contractions in normal bathing fluid significantly, whereas contractions in $\mathrm{Ca}^{++}$-free fluid induced by norepinephrine and caffeine were inhibited only by a high concentration $\left(10^{-3} \mathrm{M}\right)$ of pentobarbitone. Caffeine-induced contractions of chemically skinned fibres were more susceptible to inhibition by thiopentone than by pentobarbitone. These results suggest that the vasodilator effect of thiopentone is mediated via its intracellular inhibitory effect and that, in contrast, the vasodilator effect of pentobarbitone can be attributed mainly to its $\mathrm{Ca}^{++}$-channel blocking action.

Le but de cette étude était d'élucider les mécanismes vasodi. latateurs des barbituriques. Sur des bandelettes spiralées de

\section{Key words}

ANAESTHETICS, INTRAVENOUS: thiopentone, pentobarbitone;

MUSCLE: smooth;

ARTERIES: mesenteric.

From the Department of Anesthesia, Kyoto University

Hospital, Sakyo-ku, Kyoto 606-01, Japan.

*Present address: Department of Anesthesiology,

Wakayama Medical College, 7-1, Wakayama-shi 640, Japan

Address correspondence to: Dr. K. Nakamura.

Accepted for publication I6th February, 1992. l'artère mésentérique du chien, nous avons vérifié les effets d'un traitement préparatoire au moyen de thiopental et de pentobarbital sur les contractions induites par du KCl $(2,0 \times$ $\left.10^{-2} \mathrm{M}\right)$ et de la norépinéphrine $\left(10^{-5} \mathrm{M}\right)$ dans un liquide de bain normal, ainsi que sur celles induites par de la norépinéphrine et de la caféine $\left(2,5 \times 10^{-2} \mathrm{M}\right)$ dans un liquide ne contenant pas d'ions $\mathrm{Ca}^{++}$. Sur des bandelletes dénudées, nous avons également examiné leurs effets sur les contractions induites par la caféine. Le thiopental, à des concentrations supérieures à $10^{-4} \mathrm{M}$, inhibait les contractions induites par le $\mathrm{KCl}$ dans un liquide de bain normal et celles induites par la caféine dans le liquide sans $\mathrm{Ca}^{++}$et, à des concentrations supérieures à $3 \times 10^{-4} \mathrm{M}$, inhibait significativement les contractions induites par la norépinéphrine dans les liquides de bain normal et sans $\mathrm{Ca}^{++}$. Le pentobarbital, à des concentrations supérieures à $3 \times 10^{-4} \mathrm{M}$, inhibait significativement les contractions induites par le $\mathrm{KCl}$ et la norépinéphrine dans le liquide de bain normal, alors que les contractions induites par la norépinéphrine et la caféine dans le liquide sans $\mathrm{Ca}^{++}$étaient inhibées seulement par une forte concentration $\left(10^{-3} \mathrm{M}\right)$ de pentobarbital. Pour les fibres dénudées chimiquement, les contractions induites par la caféine étaient plus susceptibles à une inhibition par le thiopental que par le pentobarbital. Ces résultats suggèrent que l'effet d'inhibition intracellulaire du thiopental sert de médiateur à son effet vasodilatateur et que, par contraste, l'effet vasodilatateur du pentobarbital peut être attribué principalement à son action de bloqueur des canaux calciques.

Barbiturates exert relaxant effects on vascular smooth muscle even in clinically relevant concentrations. ${ }^{1-10}$ Some investigators have ascribed this effect to a $\mathrm{Ca}^{++}$ channel blocking action. ${ }^{2.6}$ However, we have demonstrated that thiamylal inhibits contractions which are mediated via the release of intracellularly stored $\mathrm{Ca}^{++}$, as well as those mediated by influx of extracellular $\mathrm{Ca}^{++}$, and that it exerts a relaxant effect even in $\mathrm{Ca}^{++}$-contracted skinned fibres. ${ }^{11}$ These results suggest that thiamylal reduces the sensitivity of the intracellular contractile machinery to $\mathrm{Ca}^{++}$ions. However, since it has been demonstrated that thiobarbiturates, including thiamylal 
and thiopentone, have a potent vasoconstrictor effect and oxybarbiturates such as pentobarbitone do not have the effect, ${ }^{8,12}$ the mechanisms of relaxation induced by thiobarbiturates and oxybarbiturates may also differ. This study was designed to examine whether thiopentone and pentobarbitone, which are corresponding oxy- and thiobarbiturates, have such intracellular actions as thiamylal.

\section{Methods}

The experimental protocol was approved by the Kyoto University Animal Use Committee. Nineteen male mongrel dogs, weighing 10 to $15 \mathrm{~kg}$, were anaesthetized with ketamine $\left(10 \mathrm{mg} \cdot \mathrm{kg}^{-1} i \mathrm{v}\right)$ and killed by exsanguination. Distal portions of mesenteric arteries (0.6-0.9 mm outer diameter) were isolated and cut into helical strips (approximately $20 \mathrm{~mm}$ long) with intact endothelium. Each strip was placed in a $10-\mathrm{ml}$ organ bath containing Krebsbicarbonate solution, which was maintained at $37.0 \pm$ $0.5^{\circ} \mathrm{C}$ and aerated with a mixture of $5 \% \mathrm{CO}_{2}$ and $95 \%$ $\mathrm{O}_{2}$ to maintain the $\mathrm{pH}$ between 7.35 and 7.45. The hook anchoring the upper end of each strip was connected to the lever of a force-displacement transducer (Toyo Baldwin T7-240, Japan) and changes in isometric tension were displayed on an ink-writing oscillograph (Rectigraph $8 \mathrm{~K}$, Nihon-denki Sanei Co., Japan). The resting tension was adjusted to $1.5 \mathrm{~g}$, which has been determined to be optimal for the induction of maximal contractions. $^{13}$ Before starting the experiments, each arterial strip was allowed to equilibrate for 90-120 min in the control bathing fluid, which was replaced every 15 $\min$.

Some arterial strips were chemically skinned by exposing them to saponin $\left(25 \mu \mathrm{g} \cdot \mathrm{ml}^{-1}\right)$ for $20 \mathrm{~min}$, as described previously. "These strips were bathed in a relaxant solution, which contained $2.0 \times 10^{-3} \mathrm{M}$ ethyleneglycol-bis-N, $N^{\prime}$-tetraacetic acid (EGTA), during the saponin exposure and in a relaxant solution, which contained $10^{-4} \mathrm{M}$ EGTA, thereafter. These solutions were aerated with $100 \%$ oxygen and maintained at $25^{\circ} \mathrm{C}$ throughout.

\section{Potassium chloride- and norepinephrine-induced contraction}

Repeated contractions with $\mathrm{KCl}\left(2.0 \times 10^{-2} \mathrm{M}\right)$ or norepinephrine (NE, $10^{-5} \mathrm{M}$ ) were induced in normal bathing fluid until the tensions induced by two successive applications were identical, which were designated $100 \%$ in each experiment. Between applications, the preparation was washed at least three times with fresh bathing fluid. In order to study the effects of thiopentone and pentobarbitone on the $\mathrm{KCl}$ - and $\mathrm{NE}$-induced contractions in normal bathing fluid, each arterial strip was exposed to thiopentone or pentobarbitone $\left(10^{-4}\right.$ to $\left.10^{-3} \mathrm{M}\right)$, or equivalent volumes of distilled water (control study) for $20 \mathrm{~min}$, and the tension changes induced by the required vasoconstricting agent were measured. In order to examine the effects of the barbiturates on the NE-induced contractions in $\mathrm{Ca}^{++}$-free bathing fluid, each strip was treated with thiopentone or pentobarbitone $\left(10^{-4}\right.$ to $10^{-3}$ $\mathrm{M}$ ) (or equivalent volume of distilled water for control study) for $15 \mathrm{~min}$ in normal bathing fluid and then bathed in $\mathrm{Ca}^{++}$-free Krebs-bicarbonate solution, which contained $2.0 \times 10^{-3} \mathrm{M}$ EGTA and the same concentration of barbiturates, for five minutes prior to exposure to NE. Norepinephrine-induced contractions in $\mathrm{Ca}^{++}$-free fluid was examined only once in each strip, and they were expressed in relative values taking the prior contractions induced by $\mathrm{NE}$ in $\mathrm{Ca}^{++}$-containing solution in each strip as $100 \%$.

\section{Caffeine-induced contractions}

As caffeine-induced contraction is dependent on the amount of $\mathrm{Ca}^{++}$stored in the cell, ${ }^{14-16}$ in this experiment arterial strips with intact plasma membranes or which had been skinned were treated first with $2.5 \times 10^{-2} \mathrm{M}$ caffeine in a $\mathrm{Ca}^{++}$-free solution, which contained $2.0 \times$ $10^{-2} \mathrm{M}$ EGTA ( $\mathrm{Ca}^{++}$-free Krebs-bicarbonate solution for intact fibres or relaxant solution for skinned fibres) to deplete their intracellular stores of $\mathrm{Ca}^{++}$, after which they were bathed for $20 \mathrm{~min}$ in $\mathrm{Ca}^{++}$-containing solutions $(2.5$ $\times 10^{-3} \mathrm{M} \mathrm{Ca}^{++}$for intact fibres and $10^{-4} \mathrm{M}$ for skinned fibres), followed by exposure to the appropriate $\mathrm{Ca}^{++}$-free bathing fluid for ten minutes and subsequent exposure to caffeine $\left(2.5 \times 10^{-2} \mathrm{M}\right)$. Before the third application of caffeine, strips were untreated (control) or treated with thiopentone or pentobarbitone $\left(10^{-5}\right.$ to $\left.10^{-3} \mathrm{M}\right)$.

\section{Drugs and fluids}

The drugs used were thiopentone sodium (Tanabe Pharmaceutical Co., Tokyo, Japan), pentobarbitone sodium, norepinephrine and caffeine (Nacalai Tesque, Kyoto, Japan). Caffeine was dissolved to a concentration of $10^{-2} \mathrm{M}$ in $\mathrm{Ca}^{++}$-free bathing solutions ( $\mathrm{Ca}^{++}$-free $\mathrm{Krebs}$ solution or the appropriate relaxant solution) and the normal bathing fluid was replaced by these solutions for the experiments which involved exposure to caffeine. Norepinephrine was dissolved in a solution of $0.1 \% \mathrm{w} / \mathrm{v}$ sodium pyrosulfate in distilled water. All the other drugs were dissolved in distilled water and added directly to the bathing fluid; the volumes added were less than 100 $\mu l$. Equivalent volumes of the appropriate diluents were added for the control studies. The $\mathrm{pH}$ of $10^{-1} \mathrm{M}$ thiopentone and pentobarbitone were 10.6 and 9.2 respectively, and the addition of $100 \mu \mathrm{l}$ of them to the bath did not alter the $\mathrm{pH}$ of the bathing solution. ${ }^{12}$

The Krebs-bicarbonate solution contained $\left(\times 10^{-3} \mathrm{M}\right)$ : 


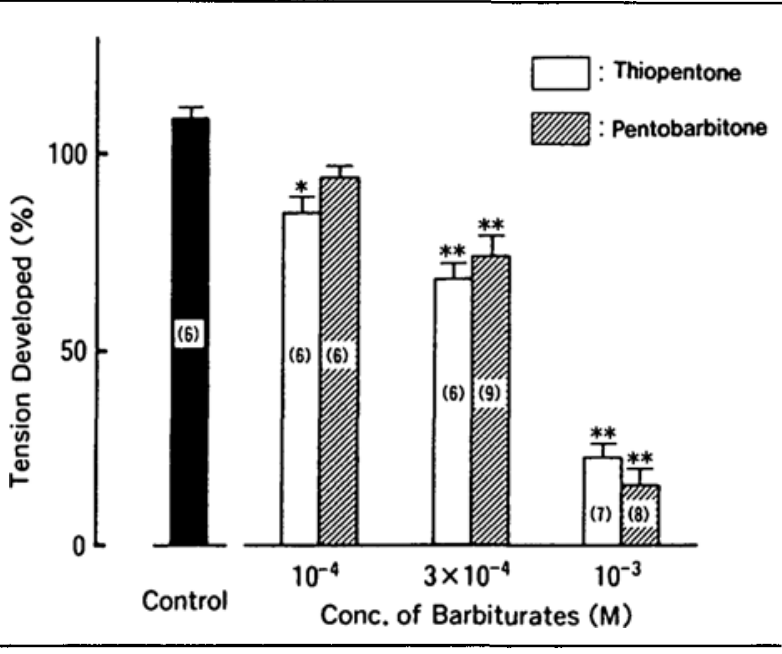

FIGURE 1 Modification by thiopentone and pentobarbitone of contractions induced by $\mathrm{KCl}\left(2.0 \times 10^{-2} \mathrm{M}\right)$. The $\mathrm{KCl}$-induced contraction of each strip prior to treatments was designated $100 \%$; the mean absolute value was $898 \pm 484 \mathrm{mg}(n=19)$. Values in parentheses indicate the number of strips studied; ${ }^{*} P<0.05$, ${ }^{* *} P<$ 0.01 versus control values.

$\mathrm{NaCl} 118.2 ; \mathrm{KCl} 4.6 ; \mathrm{CaCl}_{2} 2.5 ; \mathrm{KH}_{2} \mathrm{PO}_{4} 1.2 ; \mathrm{MgSO}_{4}$ 1.2; $\mathrm{NaHCO}_{3} 24.8$ and dextrose 10. The $\mathrm{Ca}^{++}$-free Krebs'-bicarbonate solution contained no $\mathrm{Ca}^{++}$but did contain $2.0 \times 10^{-3} \mathrm{M}$ EGTA and the other constituents were as described for the Krebs-bicarbonate solution. The relaxant solution contained $\left(\times 10^{-3} \mathrm{M}\right): \mathrm{KCl} 130$; Tris-malate $20 ; \mathrm{MgCl}_{2} 2$; adenosine triphosphate (ATP) 3 and $\mathrm{NH}_{4}$, which was added to adjust the $\mathrm{pH}$ to $6.75-6.85$.

\section{Statistical analysis}

Each response was expressed as a percentage of the response obtained prior to treatment in the same strip except for the response to $\mathrm{NE}$ in $\mathrm{Ca}^{++}$free condition, which was expressed relative to that in $\mathrm{Ca}^{++}$-containing solution. The control value represents the response of strips treated with distilled water alone, in a volume equal to the barbiturate-containing solution, relative to the previous response in the same strip. The data were expressed as means \pm SEM and analyzed by analysis of variance and Newman Keuls' multiple range test. A $P$ value $<0.05$ was considered to be significant.

\section{Experimental design}

The effects of pretreatment with thiopentone and pentobarbitone on the contractions induced by $\mathrm{KCl}$ and $\mathrm{NE}$ in normal bathing fluid and on those induced by NE and caffeine in $\mathrm{Ca}^{++}$-free fluid in intact strips, and on caffeine-induced contractions in skinned strips were examined.

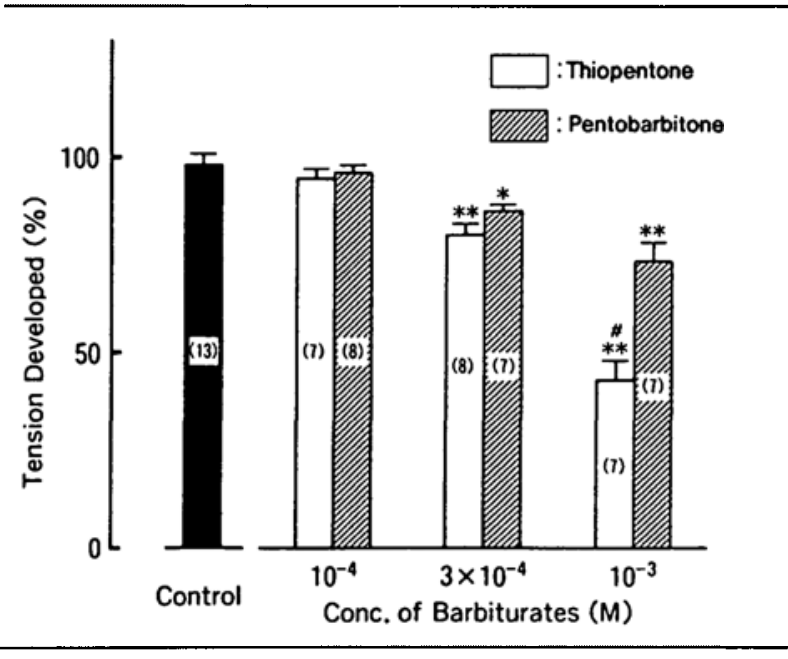

FIGURE 2 Modification by thiopentone and pentobarbitone of contractions induced by NE $\left(10^{-5} \mathrm{M}\right)$ in normal bathing solution. The NE-induced contraction of each strip prior to treatments was designated $100 \%$; the mean absolute value was $2757 \pm 1374 \mathrm{mg}$ ( $n$ $=21$ ). Values in parentheses indicate the number of strips studied; $* P<0.05, * * P<0.01$ versus control values. $\# P<0.05$ thiopentone versus pentobarbitone in the same concentrations.

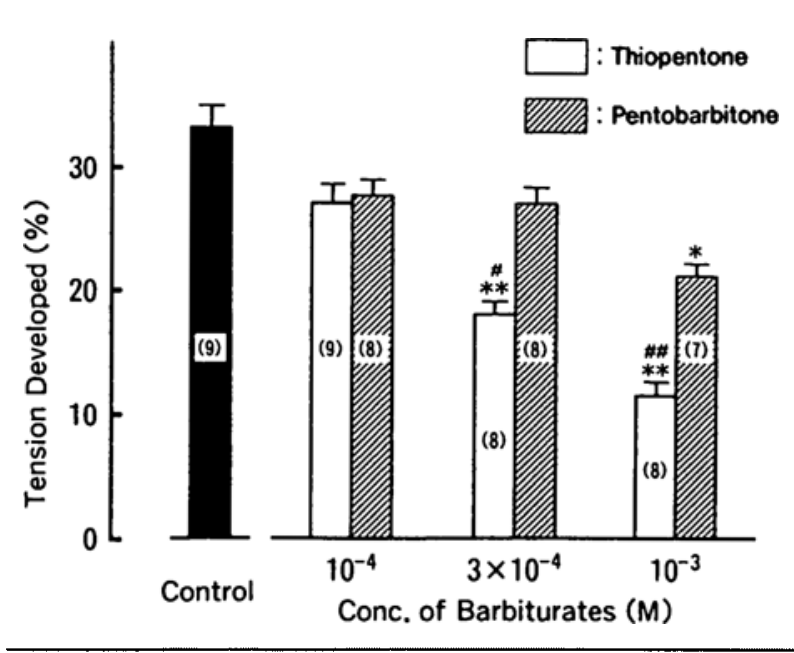

FIGURE 3 Modification by thiopentone and pentobarbitone of contractions induced by NE $\left(10^{-5} \mathrm{M}\right)$ in $\mathrm{Ca}^{++}$-free solution. The NEinduced contraction of each strip in normal bathing fluid prior to treatment was designated $100 \%$; the mean absolute value was 3677 $\pm 1246 \mathrm{mg}(n=30)$. Values in parentheses indicate the number of strips studied; $* P<0.05,{ }^{* *} P<0.01$ versus control values. $\# P<$ $0.05, \# P<0.01$ thiopentone versus pentobarbitone in the same concentrations.

\section{Results}

The contractions induced by $\mathrm{KCl}$ were inhibited by thiopentone and pentobarbitone, at concentrations greater than $10^{-4} \mathrm{M}$ and $3 \times 10^{-4} \mathrm{M}$ respectively $(P<0.05)$, but the inhibition produced by thiopentone was not dif- 


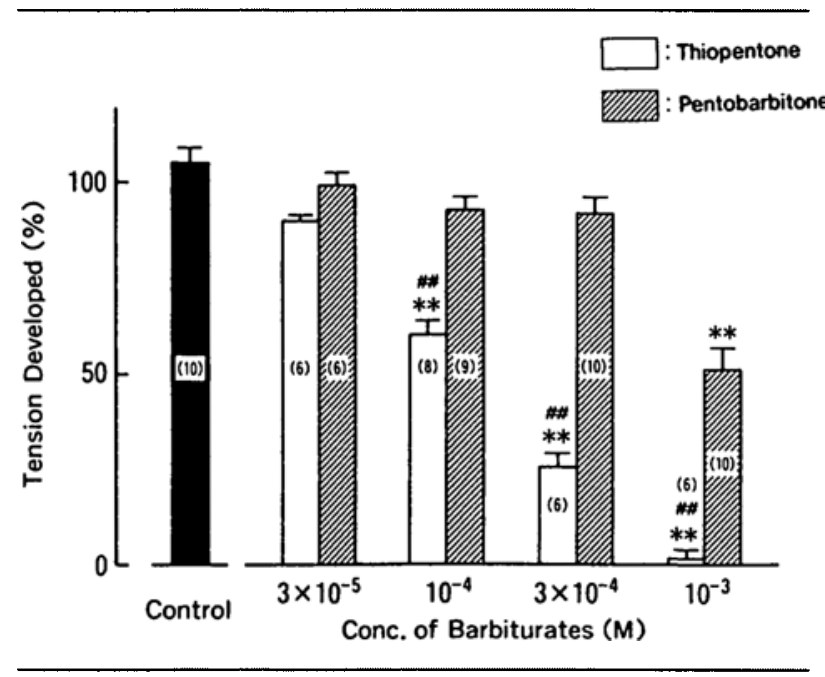

FIGURE 4 Modification by thiopentone and pentobarbitone of contractions induced by caffeine $\left(2.5 \times 10^{-2} \mathrm{M}\right)$ in intact fibres. The caffeine-induced contraction of each strip prior to treatment was designated 100\%; the mean absolute value was $411 \pm 207 \mathrm{mg}(n=$ 18). Prior to each application of caffeine, the arterial strips were loaded with $\mathrm{Ca}^{++}\left(2.5 \times 10^{-3} \mathrm{M}\right)$ for $20 \mathrm{~min}$ and then bathed in $\mathrm{Ca}^{++}$-free relaxant solution, with or without thiopental and pentobarbital. Values in parentheses indicate the number of strips studied; ${ }^{*} P<0.01$ versus control values. \#P<0.01 thiopentone versus pentobarbitone in the same concentrations.

ferent from that by pentobarbitone at corresponding concentrations (Figure 1).

Norepinephrine-induced contractions in normal bathing fluid $\left(\mathrm{Ca}^{++} 2.5 \times 10^{-3} \mathrm{M}\right)$ were attenuated by thiopentone and pentobarbitone, at concentrations greater than $3 \times 10^{-4} \mathrm{M}(P<0.05)$, and the attenuation induced by $10^{-3} \mathrm{M}$ thiopentone was greater than that induced by $10^{-3} \mathrm{M}$ pentobarbitone $(P<0.05)$ (Figure 2$)$.

Norepinephrine-induced contractions in $\mathrm{Ca}^{++}$-free bathing fluid, the mean of which was $32.2 \pm 7.5 \%$ of that in normal bathing fluid (control group), were inhibited by thiopentone and pentobarbitone at concentrations greater than $3 \times 10^{-4} \mathrm{M}$ and $10^{-3} \mathrm{M}$ respectively $(P<$ 0.05 ) (Figure 3 ). The attenuations induced by thiopentone ( $\geqq 3 \times 10^{-4} \mathrm{M}$ ) were greater than those of pentobarbitone at corresponding concentrations $(P<0.05)$.

Caffeine-induced contractions in intact fibres were inhibited by thiopentone at over $10^{-4} \mathrm{M}$ and pentobarbitone at only $10^{-3} \mathrm{M}(P<0.01)$ (Figure 4$)$. The inhibitory effects of thiopentone ( $\geqq 10^{-4} \mathrm{M}$ ) were greater than those of pentobarbital at corresponding concentrations $(P$ $<0.01)$. Caffeine-induced contractions of skinned fibres were inhibited by thiopentone at concentrations greater than $10^{-5} \mathrm{M}$ and pentobarbitone $3 \times 10^{-4} \mathrm{M}(P<0.01)$ (Figure 5). The inhibitory effects of thiopentone $\left(\geqq 10^{-5}\right.$ M) were greater than those of pentobarbitone at corresponding concentrations $(P<0.01)$.

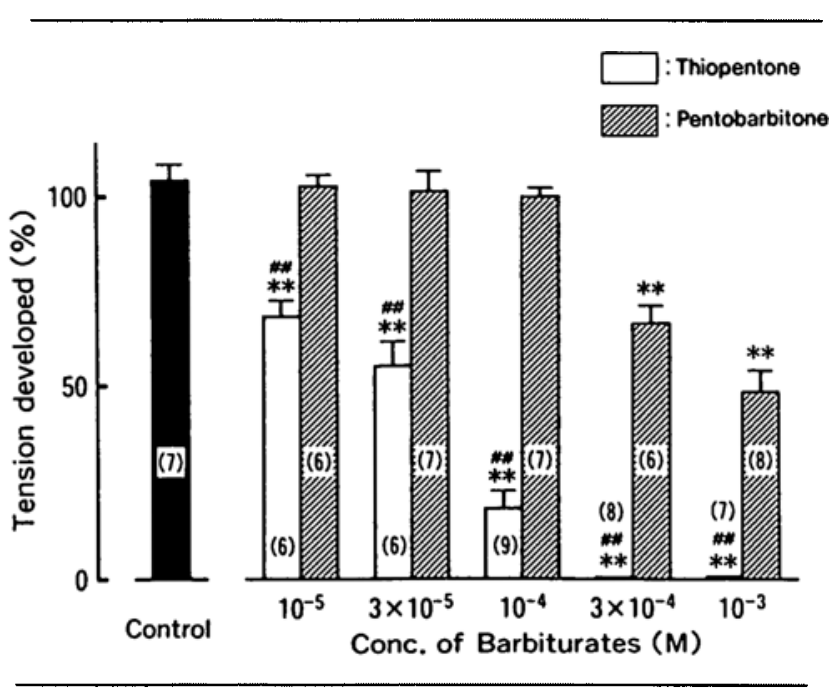

FIGURE 5 Modification by thiopentone and pentobarbitone of contractions induced by caffeine $\left(2.5 \times 10^{-2} \mathrm{M}\right)$ in chemically skinned fibres. The caffeine-induced contraction of each strip prior to treatments was designated $100 \%$; the mean absolute value was $329 \pm 148 \mathrm{mg}(n=35)$. Prior to each application of caffeine, the arterial strips were loaded with $\mathrm{Ca}^{++}\left(10^{-4} \mathrm{M}\right)$ for $20 \mathrm{~min}$ and then bathed in $\mathrm{Ca}^{++}$-free relaxant solution, with or without barbiturates. Values in parentheses indicate the number of strips studied; **P< 0.01 versus control values. \#\# $<0.01$ thiopentone versus pentobarbitone in the same concentrations.

\section{Discussion}

We have previously demonstrated that endothelium-independent vasodilation is induced by pentobarbitone at concentrations over $10^{-4} \mathrm{M}$, and by thiopentone and thiamylal at over $3 \times 10^{-4} \mathrm{M}$, in dog mesenteric arteries precontracted with $\mathrm{KCl}$ or prostaglandin $\mathrm{F}_{2 \alpha}{ }^{8}$ The plasma level of thiopentone necessary for anaesthesia has been reported to be $1.5 \times 10^{-4} \mathrm{M}$ in humans, ${ }^{17}$ and the peak level of barbiturates following rapid induction, or that of oxybarbiturates when large doses were administered for cerebral protection may be higher than this. Therefore, concentrations of barbiturates which induced vasodilatation in the dog mesenteric artery may be close to clinically relevant concentrations in humans.

In this study, we compared the influence of thiopentone and pentobarbitone on contractions elicited by $\mathrm{KCl}$, $\mathrm{NE}$ and caffeine, which induce contractions via different mechanisms. Potassium chloride elicits contractions by increasing $\mathrm{Ca}^{++}$-influx through voltage-dependent $\mathrm{Ca}^{++}$ channels and caffeine induces contraction by facilitating $\mathrm{Ca}^{++}$induced $\mathrm{Ca}^{++}$release from the sarcoplasmic reticulum (SR). ${ }^{15,16}$ Norepinephrine increases $\mathrm{Ca}^{++}$-influx through receptor-operated $\mathrm{Ca}^{++}$-channels and increases the release of intracellularly stored $\mathrm{Ca}^{++}$, which is mediated by inositol 1,4,5-triphosphate (IP3). ${ }^{18,19}$ Therefore, NE-induced contractions in normal bathing fluid can be considered to be due to the summation of those mediated 
TABLE The minimum concentrations of barbiturates required to inhibit contractions significantly

\begin{tabular}{lll}
\hline & Thiopentone & Pentobarbitone \\
\hline $\begin{array}{l}\mathrm{KCl} \text {-induced contraction } \\
\mathrm{NE} \text {-induced contraction in } \\
\text { normal } \mathrm{Ca}^{++} \text {solution }\end{array}$ & $10^{-4} \mathrm{M}$ & $3 \times 10^{-4} \mathrm{M}$ \\
$\begin{array}{l}\mathrm{NE} \text {-induced contraction in } \\
\mathrm{Ca}^{++} \text {-free solution } \\
\begin{array}{l}\text { Caffeine-induced contrac- } \\
\text { tion of intact strips }\end{array}\end{array}$ & $3 \times 10^{-4} \mathrm{M}$ & $3 \times 10^{-4} \mathrm{M}$ \\
\hline
\end{tabular}

by $\mathrm{Ca}^{++}$-influx and $\mathrm{Ca}^{++}$-release and contraction in $\mathrm{Ca}^{++}$free fluid, containing $2.0 \times 10^{-3} \mathrm{M}$ EGTA, can be considered to approximate that mediated by $\mathrm{Ca}^{++}$-release alone. $^{5.19}$

This study demonstrated that the sensitivities of the contractions induced by $\mathrm{KCl}, \mathrm{NE}$ and caffeine to the inhibitory effects of pentobarbitone or thiopentone differ (Table). Pentobarbitone inhibited $\mathrm{KCl}$-induced contractions to a greater extent than those mediated via $\mathrm{Ca}^{++}$release, including those induced by caffeine and by $\mathrm{NE}$ in $\mathrm{Ca}^{++}$-free fluid. Furthermore, contractions induced by $\mathrm{NE}$ in normal $\mathrm{Ca}^{++}$-containing fluid were more susceptible to pentobarbitone than those in $\mathrm{Ca}^{++}$-free fluid. These results agree with those of other authors ${ }^{1,3-8}$ and support the hypothesis that pentobarbitone inhibits $\mathrm{Ca}^{++}$-influx through both voltage-dependent and receptor-operated channels of plasma membranes. ${ }^{2.6}$ However, in contrast to pentobarbitone, thiopentone inhibited contractions induced by caffeine to the same extent as those induced by $\mathrm{KCl}$, which suggests that the mechanism underlying the relaxant effects of thiopentone and pentobarbitone differ. $^{21}$

Treatment with saponin renders plasma membranes porous and such muscle fibres are described as chemically skinned. Therefore, using skinned fibres, the effects of any agent in the absence of the influence of $\mathrm{Ca}^{++}$-movement across the plasma membrane can be studied. Our previous study" demonstrated that thiamylal inhibited $\mathrm{Ca}^{++}$-induced contractions in dog mesenteric arterial skinned fibres strongly, which indicates that thiamylal reduced the sensitivity of the intracellular contractile machinery to $\mathrm{Ca}^{++}$. In this study, we tested the effects of barbiturates on caffeine-induced contraction of skinned and intact fibres, and found that thiopentone exerted inhibitory effects on caffeine-induced contractions of skinned fibres at very low concentrations, which indicates that the action of thiopentone is not limited to the plasma membranes. Furthermore, these findings with thiopentone can be explained by the hypothesis that thiopentone, but not pentobarbitone, reduced the sensitivity of the vascular smooth muscle intracellular contractile<smiles>CCCC(C)C1(CC)C(=O)NC(=S)NC1=O</smiles>

\section{Thiopentone}<smiles>CCCC(C)C1(CC)C(=O)NC(=O)NC1=O</smiles>

\section{Pentobarbitone}

FIGURE 6 The chemical structures of thiopentone and pentobarbitone.

machinery to $\mathrm{Ca}^{++}$in the same, or a similar manner, as thiamylal. ${ }^{11}$ Moreover, as thiopentone and pentobarbitone are corresponding thio- and oxybarbiturates (Figure 6), these results suggest that different mechanisms may underlie the relaxations induced by thio- and oxybarbiturates.

In addition, although it has been generally accepted that plasma membranes are quite permeable to barbiturates, the finding that caffeine-induced contractions of muscle fibres with intact plasma membranes were less susceptible to thiobarbiturates than those which had been skinned, indicates that a barbiturate concentration gradient across the intact plasma membrane may exist.

In this study, contractions induced by NE were less susceptible to thiopentone than those induced by $\mathrm{KCl}$ and caffeine, which agrees with the results obtained with thiamylal in our previous study. "It has been demonstrated that thiobarbiturates, such as thiopentone and thiamylal, in concentrations of $10^{-5}$ to $10^{-4} \mathrm{M}$, potentiate $\mathrm{NE}$-induced contractions of the rabbit isolated pulmonary artery or rat isolated aorta. ${ }^{7,20.21}$ This effect may counteract the relaxant effect of thiopentone and could, therefore, account for the lower susceptibility of NE-induced contractions to thiopentone compared with those of $\mathrm{KCl}$ or caffeine-induced contractions.

In summary, thiopentone inhibited contractions elicited by $\mathrm{Ca}^{++}$-influx and $\mathrm{Ca}^{++}$-release to the same extent, whereas pentobarbitone inhibited contractions elicited by 
$\mathrm{Ca}^{++}$influx selectively. We hypothesize that the vasodilator effect of pentobarbitone is due mainly to a non-specific $\mathrm{Ca}^{++}$-channel blocking action, whereas thiopentone, as does thiamylal, reduces the sensitivity of the vascular smooth muscle intracellular contractile machinery to $\mathrm{Ca}^{++}$.

\section{References}

1 Altura BT, Altura BM. Barbiturates and aortic and venous smooth-muscle function. Anesthesiology 1975; 43: 432-44.

2 Altura BM, Turlapaty PDMV, Altura BT. Pentobarbital sodium inhibits calcium uptake in vascular smooth muscle. Biochim Biophys Acta 1980; 595: 309-12.

3 Edvinson $L, M c$ Culloch J. Effects of pentobarbital on contractile responses of feline cerebral arteries. J Cereb Blood Flow Metab 1981; 1: 437-40.

4 Marin J, Lobato RD, Rico ML, Salaices M, Benitez J. Effects of pentobarbital on the reactivity of isolated human cerebral arteries. J Neurosurg 1981; 54: 521-4.

5 Sanchez-Ferrer CF, Marin J, Salaices $M$, et al. Interference of pentobarbital and thiopental with the vascular contraction and noradrenaline release in human cerebral arteries. Gen Pharmacol 1985; 16: 469-73.

6 Wendling $W W$, Haracal $C$. Comparative actions of pentobarbital and verapamil on canine cerebral and peripheral arteries in vitro. Res Commun Chem Pathol Pharmacol 1985; 49: 189-202.

7 Nakamura K, Hatano Y, Nishiwada M, Yakushiji T, Park JW, Mori $K$. Effects of thiobarbiturates on smooth muscle reactivity in isolated aortas from spontaneously hypertensive rats. Anesth Analg 1990; 70: 267-74.

8 Moriyama S, Nakamura K, Hatano $Y$, Harioka $T$, Mori $K$. Responses to barbiturates of isolated dog cerebral and mesenteric arteries contracted with $\mathrm{KCl}$ and prostaglan$\operatorname{din} \mathrm{F}_{2 \alpha^{*}}$. Acta Anaesth Scand 1990; 34: 523-9.

9 Taga K. Fukuda S, Nishimura N, Tsukui A, Morioka M, Shimoji $K$. Effects of thiopental, pentobarbital, and ketamine on endothelin-induced constriction of porcine cerebral arteries. Anesthesiology 1990; 72: 939-41.

10 McShane AJ, Crowley K, Shayevitz JR, Michael JR, Adkinson NF, Traystman RJ. Barbiturate anesthetics inhibit thromboxane-, potassium-, but not angiotensininduced pulmonary vasoconstriction. Anesthesiology 1989; 70: 775-9.

11 Nakamura $K$, Hatano $Y$, Nishiwada M, Mori $K$. The vasodilator effect of thiamylal in dog mesenteric artery. Can J Phys Pharmac 1991; 69: 1163-7.

12 Hatano $Y$, Nakamura $K$, Moriyama $S$, Mori $K$, Toda $N$. The contractile responses of isolated dog cerebral and extracerebral arteries to oxybarbiturates and thiobarbiturates. Anesthesiology 1989; 71: 80-6.
13 Tada N, Hatano Y, Hayashi S. Modifications by stretches of the mechanical response of isolated cerebral and extracerebral arteries to vasoactive agents. Pflugers Arch Eur J Physiol 1978; 374: 73-7.

14 Itoh $T$, Kuriyama $H$, Suzuki $H$. Excitation-contraction coupling in smooth muscle cells of the guinea-pig mesenteric artery. J Physiol 1981; 321: 513-35.

15 Su JY, Zhang CC. Intracellular mechanism of halothane's effect on isolated aortic strips of the rabbit. Anesthesiology 1989; 71: 409-17.

16 Kanmura $Y$, Yoshitake J, Casteels $R$. Ketamine-induced relaxation in intact and skinned smooth muscles of the rabbit ear artery. Br J Pharmaco 1989; 97: 591-7.

17 Becker KE. Plasma levels of thiopental necessary to anesthesia. Anesthesiology 1978; 49: 192-6.

18 Godfraind $T$, Miller $R C$. Actions of prostaglandin $F_{2 n}$ and noradrenaline on calcium exchange and contraction in rat mesenteric arteries and their sensitivity to calcium entry blockers. Br J Pharmacol 1982; 75: 229-36.

19 Hashimoto $T$, Hirata $M$, Itoh $T$, Kanmura $Y$, Kuriyama $H$. Inositol 1,4,5 triphosphate activates pharmacomechanical coupling in smooth muscle of the rabbit mesenteric artery. J Physiol 1986; 370: 605-18.

20 Fukuda S, Inomata I, Tsuji T, Takeshita H. Thiopental potentiation of isolated rabbit pulmonary artery contractions with alpha receptor agonist. Anesthesiology 1984; 60: 187-92.

21 Nishiwada $M$, Nakamura $K$, Hatano Y, Mori $K$. The relaxing effects of barbiturates in vascular smooth muscle of rat aorta. Journal of Anesthesia 1991; 5: 380-7. 